\title{
Endoscopic Management of Sigmoid Volvulus in a Debilitated Population: What Relevance?
}

\author{
Manuel Coelho da Rocha Tiago Capela Mário Jorge Silva Gonçalo Ramos \\ João Coimbra
}

Gastroenterology Department, Centro Hospitalar Universitário de Lisboa Central, Lisbon, Portugal

\section{Keywords}

Volvulus · Sigmoid · Elderly · Endoscopy · Surgery

\section{Abstract}

Background: Colonic volvulus, mainly from the sigmoid, is a relatively common cause of intestinal obstruction, particularly in the elderly and in patients with debilitating conditions. The high morbi-mortality of emergency surgery places the endoscopic approach as the first-line treatment for the resolution of this acute obstructive condition. Objectives: To assess the importance of endoscopic treatment for the resolution of colonic volvulus in a debilitated population. Method: This is a retrospective analysis of emergency lower gastrointestinal endoscopies in patients with colonic volvulus as diagnosis, performed over a 9-year period (2009-2018), as well as population characterization and follow-up after the first exam. Results: We performed 88 procedures in 52 patients (56.4\% males, median age 83 years, range 33-94). Endoscopic resolution was effective in $86.4 \%$ (76/88) of the exams, without procedure complications. Eighty-one percent of patients presented with volvulus recurrence, $50 \%$ of which occurred during the 3 months after the initial procedure. Twenty-one were submitted to surgery, 12 of which were emergency procedures after endoscopic failure as the primary treatment ( 5 of which had mucosal necrosis at en- doscopy). There was no mortality in elective surgery. In the emergency plus necrosis group, mortality was $60 \%$ (3/5) and $14.3 \%(1 / 7)$ in the emergency without necrosis group. Conclusions: Despite the high recurrence of volvulus after endoscopic treatment, it seems to be an adequate and low-risk first-line therapy for sigmoid volvulus in debilitated patients, allowing improvement of surgical conditions.

(c) 2019 Sociedade Portuguesa de Gastrenterologia Published by S. Karger AG, Basel

Terapêutica endoscópica do volvo sigmoideu numa população debilitada - qual a relevância?

\section{Palavras Chave}

Volvo $\cdot$ Sigmoideia $\cdot$ Idoso $\cdot$ Endoscopia $\cdot$ Cirurgia

\section{Resumo}

Introdução: O volvo cólico, particularmente da sigmoideia, é uma causa relativamente comum de obstrução intestinal, sobretudo em idosos ou doentes com condições debilitantes. A elevada morbi-mortalidade do procedimento cirúrgico de urgência coloca a abordagem endoscópica como primeira linha na tentativa de resolução

\section{KARGER}

karger@karger.com www.karger.com/pjg
(C) 2019 Sociedade Portuguesa de Gastrenterologia Published by S. Karger AG, Basel

Karger

Upen access

This article is licensed under the Creative Commons AttributionNonCommercial-NoDerivatives 4.0 International License (CC BYNC-ND) (http://www.karger.com/Services/OpenAccessLicense). Usage and distribution for commercial purposes as well as any distribution of modified material requires written permission.
Manuel Coelho da Rocha

Gastroenterology Department, Centro Hospitalar Universitário de Lisboa Central Alameda de Santo António dos Capuchos

PT-1169-050 Lisbon (Portugal)

E-Mail manel.rocha@gmail.com 
do quadro obstrutivo agudo. Objetivos: Avaliar a importância da terapêutica endoscópica na resolução do volvo sigmoideu (inaugural ou de repetição) numa população debilitada. Métodos: Análise retrospetiva dos procedimentos endoscópicos realizados em contexto de urgência e com diagnóstico de volvo cólico, durante um período de 9 anos (2009-2018) num Serviço de Urgência de um Hospital Central, bem como caracterização demográfica da população e curso clínico após procedimento endoscópico inicial. Resultados: Realizados 88 procedimentos em 52 doentes ( $56.4 \%$ do sexo masculino, idade mediana 83 anos, intervalo 33-94). A resolução endoscópica foi conseguida em $86.4 \%$ dos procedimentos (76/88), não se registando complicações associadas ao procedimento. Um total de $81 \%$ dos doentes apresentaram recidiva de volvo após procedimento endoscópico, $50 \%$ dos quais nos 3 meses após procedimento inicial. Vinte e um doentes foram operados, 12 de urgência por não ter havido resolução endoscópica (5 destes com necrose da mucosa na endoscopia). Não se registou mortalidade nos doentes operados eletivamente. No grupo de doentes operados em urgência com necrose da mucosa cólica a mortalidade foi de $60 \%(3 / 5)$, e de $14.3 \%$ (1/7) no grupo de urgência sem necrose da mucosa. Conclusão: Apesar da elevada taxa de recorrência, a terapêutica endoscópica parece apresentar-se como uma opção de primeira linha adequada e de baixo risco na resolução de volvo cólico em doentes debilitados, permitindo melhorar condições clínicas para a realização de intervenção cirúrgica eletiva.

(๑) 2019 Sociedade Portuguesa de Gastrenterologia Publicado por S. Karger AG, Basel

\section{Introduction}

Colonic volvulus refers to the torsion of a colonic segment. Although being an uncommon cause of colonic obstruction in Western countries, it nevertheless constitutes the third leading cause of large bowel obstruction following neoplasm and diverticular disease [1]. Sigmoid volvulus (SV) represents 50-90\% of all colonic volvulus [2] and occurs when an air-filled loop of the sigmoid colon twists around its mesentery. When the degree of torsion exceeds 180 degrees, obstruction of the intestinal lumen occurs and torsion greater than 360 degrees results in impairment of vascular perfusion [3, 4]. The etiology of SV is multifactorial and controversial, with the anatomical constitution of the sigmoid colon being a prerequisite for SV. The redundancy of the sigmoid colon, dolichomesentery (described as "mesentery that is wider than long") and

Endoscopic Management of Sigmoid

Volvulus: What Relevance? narrowing of the base of the sigmoid mesentery are considered underlying factors for the development of SV. These anatomical characteristics may be acquired and, in rare cases, congenital [3]. Chronic fecal overload is believed to cause elongation and dilatation of the sigmoid colon. In Western populations it seems to be more common in elderly males (aged 70 years) and patients with obstipation, diabetes, and neuropsychiatric disorders. In addition, pregnancy and pelvic mass are described as factors leading to sigmoid torsion $[5,6]$. The annual incidence of SV in developed countries is around 1.7:100,000 per year, being responsible for $1.9-5 \%$ of admissions due to acute colonic obstruction $[2,5]$. Otherwise, in Eastern Africa, Asia, and South America (where precipitant factors such as high altitude and high-fiber diet are described as causing sigmoid torsion), SV seems to be endemic and responsible for $20-75 \%$ of admissions for acute colonic obstructions $[3,7]$ with an incidence as high as 12:100,000 per year [8]. The most common symptoms and signs are abdominal pain, abdominal distention, and obstipation, with many patients presenting an insidious onset of symptoms [9]. The differential diagnosis of SV includes colorectal neoplasia, colonic pseudo-obstruction, paralytic ileus, and toxic megacolon. The first radiological exam in the emergency room is usually a plain abdominal X-ray, which typically shows colonic dilation and the so-called "coffee bean" (the twisted loop of the sigmoid colon is said to resemble a coffee bean). However, a CT scan should be performed whenever possible as its diagnostic accuracy is superior to $90 \%$ [10]. Typical CT findings include the bird beak appearance of the afferent and efferent colonic segments and the whirl sign (representing the twisted pedicle of colon) [10] (Fig. 1). Other signs such as the presence of pneumatosis intestinalis, portal venous gas, or loss of bowel wall enhancement are suggestive of bowel necrosis.

The treatment of uncomplicated SV patients consists in emergency endoscopic detorsion. Firstly described by Bruusgaard [11], this procedure is both diagnostic and therapeutic: first of all, it allows evaluation of the mucosa and its viability; second, it is important to exclude other causes of obstruction. The area of torsion appears as a spiral, sphincter-like area of mucosa (Fig. 2). The procedure consists in endoscopic progression through the twisted mucosa with minimal insufflation and aspiration of gas in the proximal dilated colon. The colonoscope withdrawal allows colon rotation and SV resolution. The endoscopic management of SV seems to be effective, solving $75-95 \%$ of cases $[12,13]$. Despite the importance of endoscopic treatment in emergent SV the recurrence after the procedure is up to $90 \%$ [14, 15], and elective surgery a few days after initial deflation ap- 
Fig. 1. Colonic dilatation with bird beak (left) and whirl sign (right).
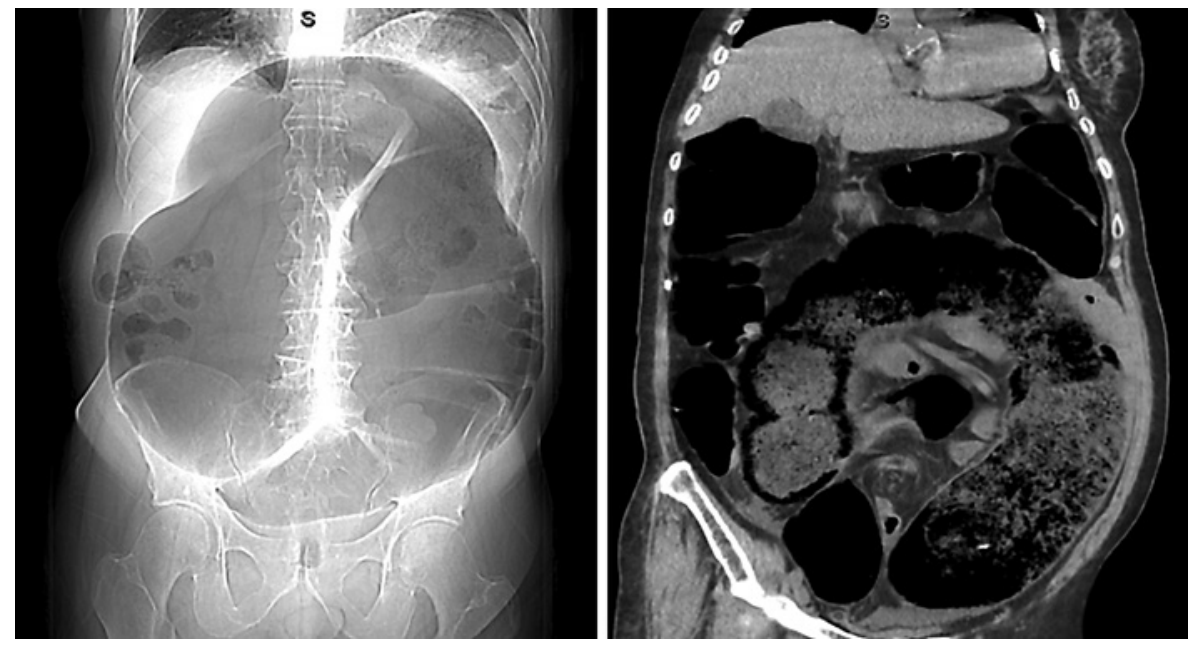

Fig. 2. Endoscopic view of colonic torsion: without mucosal suffering (left), with mucosal suffering (right).

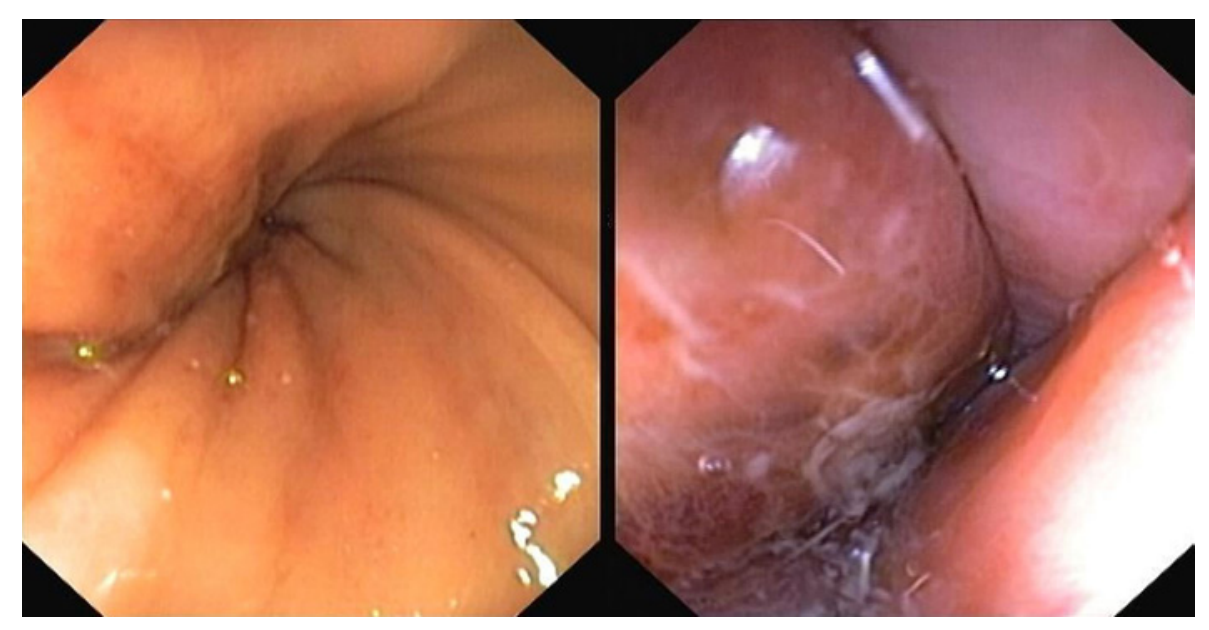

pears to be a consensual approach [15]. However, in the elderly and patients with multiple pathologies it can be postponed given the risks of surgery [16]. The timing of surgery after endoscopic resolution of volvulus, as well as whether or not to perform surgery in the elderly and patients with multiple comorbidities, remains in discussion without a clear answer $[3,16]$. Emergency surgery should be reserved for patients in whom peritonitis, bowel gangrene, or perforation is suspected or in those where endoscopic treatment is unsuccessful as mortality reaches $67 \%[3,12]$.

\section{Materials and Methods}

We performed a retrospective analysis of all emergency lower gastrointestinal endoscopies in patients with $\mathrm{SV}$ as the final diagnosis, performed between 2009 and 2018, in a tertiary care emergency service. Data on patient's demographics, medical history, endoscopic procedure details, and follow-up (including complications and further therapies) were collected. Statistical analysis was performed with Microsoft Excel $2016^{\mathrm{TM}}$ and STATA ${ }^{\circledR}$ v12.1.

\section{Results}

A total of 91 endoscopic procedures with a diagnosis of SV were found in the 9-year period. Three were excluded because of incomplete medical records or insufficient patient follow-up. All patients had a previous imagological exam with suspicion of volvulus. A total of 88 endoscopic procedures corresponding to 52 patients were considered. The average follow-up time was 20 months. The median age at the procedure was 83 years, ranging from 33 to 94 years. Every patient had at least one comorbidity potentially related to volvulus and the mean Charlson comor- 
Table 1. Demographic characteristics and population comorbidities

\begin{tabular}{ll}
\hline Age, years & \\
Median & 83 \\
Range & $33-94$ \\
Gender & \\
Male & $29(56)$ \\
Female & $23(44)$ \\
Comorbidities & \\
Constipation & $36(69.2)$ \\
Neuropsychiatric disorders & $31(59.0)$ \\
Use of obstipant drugs & $16(30.8)$ \\
Diabetes & $13(25.6)$ \\
Prior abdominal surgery & $7(12.8)$ \\
Abdominal mass & $4(7.8)$ \\
Confined to bed & $29(56.4)$ \\
\hline
\end{tabular}

Data are presented as $n(\%)$ unless otherwise indicated.

bidity index was 6 points. Thirty-six patients had prior history of obstipation and 31 had a neuropsychiatric disorder $(52.2 \%$ with stroke and $34.9 \%$ with advanced dementia). More than half of the patients were confined to bed and dependent of caregivers at the moment of the volvulus. The demographic characteristics and comorbidities of the patients are described in Table 1.

The endoscopic treatment was effective in volvulus resolution in $86.4 \%$ of cases $(76 / 88)$. In 5 of the 88 procedures, endoscopic features representing mucosal suffering (as necrosis or deep ulceration) were found, indicating the immediate suspension of the endoscopic procedure. If we exclude those 5 procedures, the endoscopic resolution of volvulus was $91.6 \%$ (76/83) (Table 2).

After the first endoscopic therapy, 7 patients were submitted to emergency surgery due to endoscopic treatment failure and 4 were submitted to elective surgery. Of the remaining 41 patients, 33 had recurrence of the volvulus (81\%). The median time between the index episode and the first recurrence was 45 days. Three months after initial SV, $53.6 \%$ of patients had a new sigmoid torsion episode, with almost all recurring in the first year. The recurrence-free survival is presented in Figure 3. A total of 36 procedures were performed on these 33 patients, which means that some patients had more than one relapse. No statistically significant difference was found in endoscopic resolution of volvulus between patients with first-time and recurrent volvulus. No complications of the endoscopic therapy were reported.

The surgical outcomes are described in Table 3. From a total of 21 patients submitted to surgery, 9 had under-

Endoscopic Management of Sigmoid

Volvulus: What Relevance?
Table 2. Endoscopic outcomes

\begin{tabular}{lll}
\hline Volvulus episode & $\begin{array}{l}\text { Endoscopic } \\
\text { exams }\end{array}$ & $\begin{array}{l}\text { Endoscopic } \\
\text { resolution }\end{array}$ \\
\hline First episode & 52 & $45(86.5)$ \\
Recurrent episode & 36 & $31(86.1)$ \\
\hline $\begin{array}{l}\text { Total } \\
\begin{array}{l}\text { Excluding patients with } \\
\text { mucosal suffering }\end{array}\end{array}$ & 88 & $76(86.4)$ \\
\hline \multicolumn{2}{c}{ Data are presented as $n$ or $n(\%)$ as appropriate. } \\
\hline
\end{tabular}

gone elective surgery (8 submitted to sigmoidectomy with primary anastomosis and 1 to sigmoidopexy) (group 1). The median time between volvulus episode and surgery in electively operated patients was 53 days. Twelve patients underwent emergency surgery: 7 without signs of mucosal suffering at endoscopy (group 2) and 5 with endoscopic features suggesting necrosis (group 3). In group 2 the procedure was sigmoidectomy with Hartmann procedure in 5 patients and sigmoidectomy with primary anastomosis in 2 . In group 3 the procedures were sigmoidectomy with Hartmann procedure (3 patients) and total colectomy with ileostomy for nonviable colon (2 patients). In group 1, no mortality was observed with a mean follow-up of 12 months, although 2 cases of anastomotic dehiscence implying surgical re-intervention and 1 case of postsurgical sepsis were reported. In group 2, 2 cases of incisional dehiscence were detected and 1 patient died from sepsis 14 days after the procedure. Finally, in group 3 the sepsis was universal due to the characteristics of the procedure, and 3 of the 5 patients died in a mean time of 6 days after the procedure.

\section{Discussion/Conclusion}

Colonic volvulus, mainly from the sigmoid colon, remains an important cause of emergency admissions, particularly in the elderly (although it can also occur in children [17]) and in patients with multiple comorbidities [3, $5,16]$. In our series, besides advanced age (median age 83 years), all of the patients had at least one condition reported as a risk factor for SV. A classical study reported that a third of all colonic emergencies in the geriatric population is due to SV [18], and surgical mortality appears to increase after the age of 70 , mainly because $50-85 \%$ of the patients have serious comorbidities [9]. This causes 
Table 3. Surgical outcomes

$$
\begin{array}{lll}
\text { Group 1 } & \text { Group 2 } \\
(n=9) & (n=7) & \begin{array}{l}
\text { Group 3 } \\
(n=5)
\end{array}
\end{array}
$$

$\begin{array}{llll}\text { Surgical morbidity } & & & \\ \text { Anastomotic dehiscence } & 2(22.2) & - & - \\ \text { Incisional dehiscence } & - & 2(28.6) & - \\ \text { Stoma infection } & - & 1(14.3) & - \\ \text { Sepsis } & 1(11.1) & 2(28.6) & 5(100) \\ \text { Surgical mortality } & 0(0) & 1(14.3) & 3(60)\end{array}$

Data are presented as $n(\%)$. Group 1: elective surgery; group 2: emergency surgery without mucosal suffering; group 3: emergency surgery with mucosal suffering.

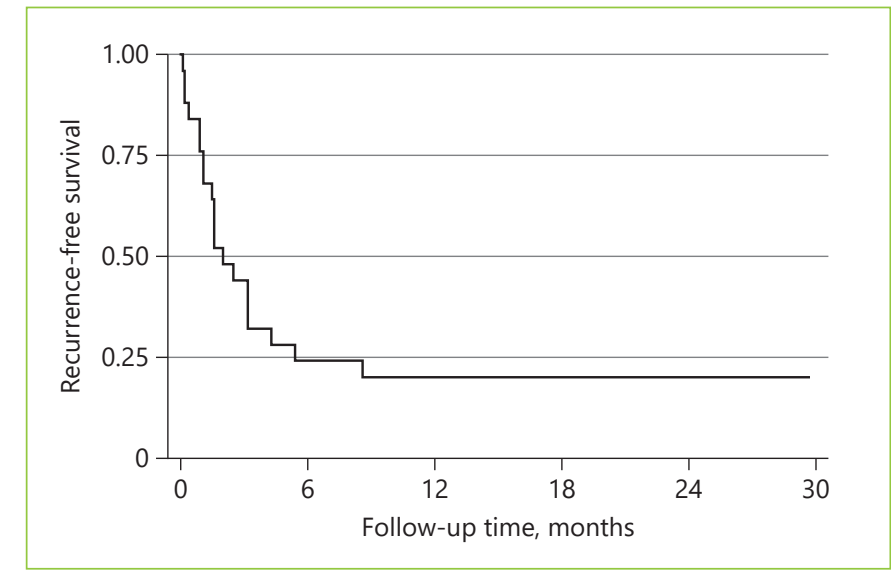

Fig. 3. Kaplan-Meier volvulus recurrence-free survival.

none in the elective group). In terms of elective surgery, sigmoid resection and primary anastomosis seems to be the gold standard with a mean mortality rate of $8 \%$ and morbidity of $13-26 \%[14,20]$. Other techniques are described, such as sigmoidopexy, but seem to carry a high recurrence risk [14]. In emergency surgery, sigmoidectomy with Hartmann procedure is recommended, although some authors perform primary anastomosis in selected cases. Regardless of the procedure in emergency surgeries, a mortality rate between 25 and $67 \%$ is expected, mainly in patients with gangrenous colon $[3,14]$. Concerning the timing of elective surgery, the median time between the index episode of SV and the first recurrence was 45 days, and most of them occurred within the first 3 months. Thus, it seems reasonable to assume that if a patient is proposed for elective surgery, it should be performed within 3 months after the first volvulus episode (ideally in the first month).

In conclusion, SV remains a cause of potentially lethal intestinal obstruction, typically seen in elderly and institutionalized patients. The endoscopic procedure has an important diagnostic and therapeutic role being effective and safe in resolving SV, despite the high recurrence expected. Elective surgery in these high-risk patients seems to be safe and preferable to emergency procedures (which have high morbi-mortality), but controlled and randomized studies with larger numbers of subjects are needed to evaluate this hypothesis.

\section{Statement of Ethics}

The authors have no ethical conflicts to disclose. 


\section{Disclosure Statement}

The authors have no conflicts of interest to declare.

\section{Author Contributions}

Manuel Coelho da Rocha prepared the manuscript. Tiago Capela, Mário Jorge Silva, Gonçalo Ramos, and João Coimbra revised the manuscript.

\section{References}

1 Grossmann EM, Longo WE, Stratton MD, Virgo KS, Johnson FE. Sigmoid volvulus in Department of Veterans Affairs Medical Centers. Dis Colon Rectum. 2000 Mar;43(3):4148.

2 Ballantyne GH, Brandner MD, Beart RW Jr, Ilstrup DM. Volvulus of the colon. Incidence and mortality. Ann Surg. 1985 Jul;202(1):8392.

3 Raveenthiran V, Madiba TE, Atamanalp SS, De U. Volvulus of the sigmoid colon. Colorectal Dis. 2010 Jul;12(7 Online):e1-17.

4 Atamanalp SS. Sigmoid volvulus. Eurasian J Med. 2010 Dec;42(3):142-7.

5 Halabi WJ, Jafari MD, Kang CY, Nguyen VQ, Carmichael JC, Mills S, et al. Colonic volvulus in the United States: trends, outcomes, and predictors of mortality. Ann Surg. 2014 Feb; 259(2):293-301.

6 Baker DM, Wardrop PJ, Burrell H, Hardcastle JD. The management of acute sigmoid volvulus in Nottingham. J R Coll Surg Edinb. 1994 Oct;39(5):304-6.

7 Asbun HJ, Castellanos H, Balderrama B, Ochoa J, Arismendi R, Teran H, et al. Sigmoid volvulus in the high altitude of the Andes. Review of 230 cases. Dis Colon Rectum. 1992 Apr;35(4):350-3.
8 Schagen van Leeuwen JH. Sigmoid volvulus in a West African population. Dis Colon Rectum. 1985 Oct;28(10):712-6.

9 Safioleas M, Chatziconstantinou C, Felekouras E, Stamatakos M, Papaconstantinou I, Smirnis A, et al. Clinical considerations and therapeutic strategy for sigmoid volvulus in the elderly: a study of 33 cases. World J Gastroenterol. 2007 Feb;13(6):921-4.

10 Levsky JM, Den EI, DuBrow RA, Wolf EL, Rozenblit AM. CT findings of sigmoid volvulus. AJR Am J Roentgenol. 2010 Jan;194(1): $136-43$.

11 Bruusgaard C. Volvulus of the sigmoid colon and its treatment. Surgery. 1947 Sep;22(3): 466-78.

12 Atamanalp SS. Sigmoid volvulus: diagnosis in 938 patients over 45.5 years. Tech Coloproctol. 2013 Aug; 17(4):419-24.

13 Anderson JR, Lee D. The management of acute sigmoid volvulus. Br J Surg. 1981 Feb; 68(2):117-20

14 Madiba TE, Thomson SR. The management of sigmoid volvulus. J R Coll Surg Edinb. 2000 Apr;45(2):74-80.
15 Larkin JO, Thekiso TB, Waldron R, Barry K, Eustace PW. Recurrent sigmoid volvulus early resection may obviate later emergency surgery and reduce morbidity and mortality. Ann R Coll Surg Engl. 2009 Apr;91(3):205-9.

16 Iida T, Nakagaki S, Satoh S, Shimizu H, Kaneto $\mathrm{H}$, Nakase $\mathrm{H}$. Clinical outcomes of sigmoid colon volvulus: identification of the factors associated with successful endoscopic detorsion. Intest Res. 2017 Apr;15(2):215-20.

17 Carmo L, Amaral M, Trindade E, HenriquesCoelho T, Pinho-Sousa J. Sigmoid volvulus in children: diagnosis and therapeutic challenge. GE Port J Gastroenterol. 2018 Sep;25(5):2647.

18 Avots-Avotins KV, Waugh DE. Colon volvulus and the geriatric patient. Surg Clin North Am. 1982 Apr;62(2):249-60.

19 Laor A, Tal S, Guller V, Zbar AP, Mavor E. The Charlson comorbidity index (CCI) as a mortality predictor after surgery in elderly patients. Am Surg. 2016 Jan;82(1):22-7.

20 Atamanalp SS, Oren D, Aydinli B, Ozturk G, Polat KY, Basoglu M, et al. Elective treatment of detorsioned sigmoid volvulus. Turk J Med Sci. 2008 Apr;38(3):227-34. 